\title{
Is Irishness part of the joke?: Martin McDonagh's drama on the Galician stage
}

\author{
Elisa Serra Porteiro
}

Department of Hispanic Studies, UCC

\section{Introduction}

My $\mathrm{PhD}$ research analyses Irish and Irish-themed plays that have been translated and performed in Galician, a minorised language spoken in Northern Spain, from J.M. Synge and W.B. Yeats to Martin McDonagh. What motivated the translation of their works? How is the adaptation process carried out? What impact have they had and continue to have? Ever since the publication of the first translations in the 1920s, the interest in Irish drama has persisted and is at present as strong as ever, with recent productions of Martin McDonagh's works enjoying successful runs on the Galician stage.

Since the mid-1990s, McDonagh has forged himself an international reputation for his daring plays and scripts, received with a great degree of enthusiasm and nearly equal measures of disapproval on the part of audiences and critics. The reactions range from flattering epithets such as "Tarantino-comes-to-Connemara" to accusations of paddywhackery and of the resurrection of the offensive "stage-Irish" in the bodies of the dysfunctional, sociopathic characters that he depicts. However, while McDonagh's works have travelled extensively, these censoring voices have not always accompanied his plays beyond Ireland. Clearly, pre-existing assumptions of Irishness affect the reception of such cultural products in other contexts. Not only that, but audiences' understanding of their own national identity can influence their reading of a play loaded with references to Irish culture, as is the case in Galicia.

\section{The Far West}

It is perched on the Atlantic. It rains. It rains a lot. The loss of population due to economically-motivated migration has shaped its social structure and the level of urbanisation is traditionally low. Sometime in the 15th century, it lost its political independence to powerful imperialist monarchs. It could be Ireland. But it isn't- it is Galicia, one of the seventeen autonomous regions that nowadays constitute the Spanish state. These and other similarities with Ireland, which could be easily applied to several other European regions, were utilised by the emerging Galician nationalist movement in the early 20th 
century as a means to legitimise political claims. Ireland had achieved independence and, according to the nationalists, Galicia could rightly pursue the same goal. Beyond the political arena, the belief that the two regions shared Celtic roots became embedded in the collective subconscious and has often been referenced in Hispanic literary circles beyond the Galician context. Such a degree of identification is bound to shape the incorporation and reception of any cultural product perceived to emanate from Ireland, regardless of the authenticity of its origin; Martin McDonagh's plays are no exception.

\section{Not Irish enough?}

Born and raised in London to Irish parents, McDonagh's borderline national identity comes up repeatedly in commentary about his works. Despite the fact that he himself has avoided pronouncing on his own degree of Irishness, the issue continues to be debated at length. In the case of many other authors with liminal identities, the question of nationality is merely a shadow in the background. Why is it constantly highlighted when it comes to Martin McDonagh? It would be simplistic to attribute this preoccupation solely to the author's "Englishness", as this would imply ignoring the trigger of the debate - his works.

In Ireland, Martin McDonagh's detractors place ethnic characterisation and the action of the plays at the same level, pointing at an offensive association of Irishness and questionable conduct, depletion, lack of education or sociopathic behaviour. His character portrayals are sometimes considered insulting and have been labelled in the media a "mockery of Ireland", a resurrection of the "stage-Irish fool" and "paddywhackery".

It is worth noting that stereotypes are largely recognisable as such by the described social group, while for outsiders they are often regarded as almost inevitable descriptive generalisations. In this line, the sin of "paddywhackery" can only be committed by the other, by someone who does not truly belong.

\section{Irishness is in the eye of the beholder}

Some of the most controversial aspects of McDonagh's plays connect to the way in which he bestows Irishness upon his characters. In the so-called "Leenane Trilogy", the action takes place in a location homonymous to the Co. Galway town. However, several geographical references do not correspond to its real-life counterpart, hinting towards a fictitious dramatic setting while still maintaining the illusion of realism that allows McDonagh's work to reach out to the spectator. Also, the use of distinctly Irish phraseology, slang and turns of phrase provides characters with an ethnic identity, to the point that the speech of these dramatic personae is so consistently loaded with Irish features as to undermine its verisimilitude. In all three Leenane-set plays, we find abundant cultural 
references that tie action and dialogue to an Irish context - Kimberleys and Jaffa cakes, poteen, Taytos, etc. In the frame of realistic depiction created by those markers, the inhabitants of this stage-Leenane exhibit dysfunctional, questionable and violent behaviour, sometimes so absurd or extreme that they slide into the caricaturesque.

Inevitably, all of these characterisation strategies operate at a different level once the plays are subjected to a translation process. Cultural references are decoded by translators, directors, actors and other participants in the process, who then must encode them again, to a greater or lesser degree, to confer them with meaning for the intended audience. Approaches can vary but translation always occurs in a specific socio-cultural context and is affected by stakeholders' preconceptions, prior experiences and perceptions of their own identity.

In the case of Galicia, the importation of Irish cultural products has historically been affected by the mystified connection between the two nations. Ireland is not only a political model but also somewhat of a mirror image of Galicia. In the course of an interview, I asked Avelino González, translator of the Leenane Trilogy into Galician, why he had taken the initiative to work on these plays: "I read McDonagh and I said to myself: "Damn, these guys are us"'.

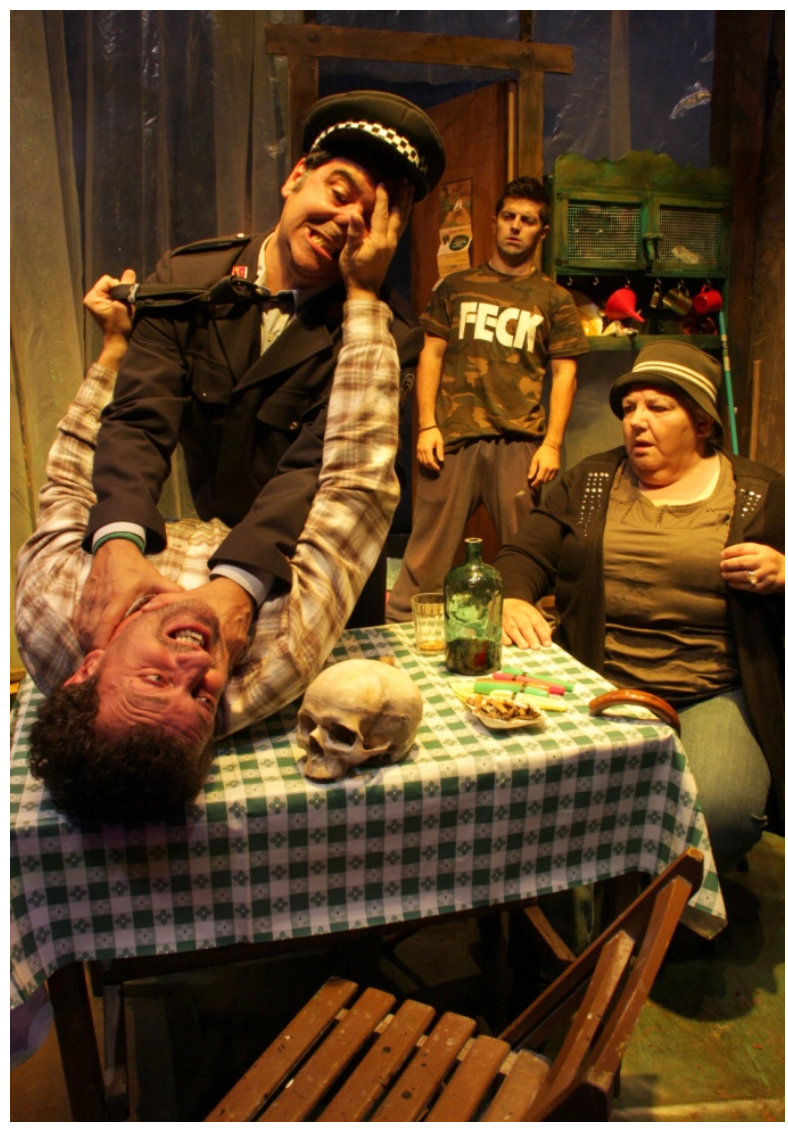

Figure 1: Un cranio en Connemara/A Skull in Connemara by Producións Excéntricas (2010). Photo: Pablo Silva 


\section{Conclusion}

Instead of being problematic, Martin McDonagh's stereotyped - or rather, typified - representation of Ireland is utilised on the Galician stage. The borderline absurd realism of the plays is maintained and so is the empathic acting approach. The characteristic Irish lingo is replaced by a dialect of Galician vaguely linking the action to a coastal area. And the stage is filled with cultural references that transport the audience to Ireland - the calendar with The Quiet Man on it, the Manchester United "Keane" jersey, and the traditional music. It is not a question of authenticity; it is all wholly about providing a code that effectively connects with the stalls. If the reception of the plays in terms of reviews and attendance is anything to go by, we can talk about a success story. Others would simply call it "paddywhackery".

This article is based on research carried out for the $\mathrm{PhD}$ research project Representations of Irish Identity on the Galician Stage, supported by the Department of Hispanic Studies, UCC, and the Irish Research Council. I would like to thank my supervisor, Dr Helena Buffery for her guidance and support.

\section{Further Reading}

González, Avelino. Personal interview. 6 Sept. 2011.

McKinty, Adrian. "Is Martin McDonagh Irish Enough?". The Psychopathology of Everyday Life: Adrian McKinty's Blog. 10 Feb. 2009. 4 July 2012. http://adrianmckinty.blogspot.ie/2009/02/is-martin-mcdonagh-irish-enough.html MacDonald, Henry. The Guardian profile: Martin McDonagh. 25 April 2008. 4 July 2012, http://www.guardian.co.uk/film/2008/apr/25/theatre.northernireland O'Neill, Elizabeth. Theatre Review: The Lieutenant of Inishmore. 1 Oct. 2003. 4 July 2012, http: //www.rte.ie/ten/2003/1002/inishmore.htm 